\title{
Prawa podatnika w zakresie odliczania podatku naliczonego w orzecznictwie Naczelnego Sądu Administracyjnego uwzględniającym prawo Unii Europejskiej oraz wyroki Trybunału Sprawiedliwości
}

\section{Wstęp ${ }^{1}$}

Podatek od wartości dodanej (VAT) jako podatek pośredni to niezwykle istotny element obrotu gospodarczego zarówno w aspekcie krajowym, jak i - z uwagi na jego harmonizację - unijnym. Warto chociażby podkreślić, że wpływy z tytułu VAT stanowią ważny fragment budżetów krajów członkowskich, który pozwala na sfinansowanie znacznej części wydatków publicznoprawnych. Z uwagi na wspomniany wcześniej pośredni charakter tego podatku kluczowego znaczenia nabierają zasady związane z dokonywaniem jego prawidłowego obliczania przez podatników. Chodzi tutaj o właściwe ustalenie wysokości zobowiązania podatkowego, na które nakładają się z jednej strony podatek należny, z drugiej zaś skorzystanie przez podatnika z przysługującego mu prawa do odliczenia podatku naliczonego.

Celem niniejszej publikacji jest omówienie podstawowych zasad podatku od wartości dodanej w świetle przepisów UE, ze szczególnym uwzględnieniem zasady neutralności podatku VAT dla podatników, która realizuje się poprzez obniżanie wysokości zobowiązania podatkowego dokonywanej za pomocą odliczania podatku naliczonego.

Ponieważ kwestia ta budzi w literaturze przedmiotu szereg wątpliwości zarówno praktycznych, jak i teoretycznych, istotnym elementem publikacji jest omówienie najważniejszego orzecznictwa sądów Unii i krajowych w zakresie realizacji zasady neutralności. Wybrane przeze mnie wyroki wskazują jednoznacznie zarówno na kluczowe znaczenie zasady neutralności dla prawidłowego funkcjonowania całego systemu podatku od wartości dodanej, jak i na konieczność jej pełnego respektowania przez aparat skarbowy państw członkowskich.

${ }^{1}$ Dr Michał Kobylarz, adiunkt w Collegium Medicum Uniwersytetu Jagiellońskiego, Wydział Farmaceutyczny, Zakład Farmacji Społecznej. 


\section{Podstawowe zasady podatku od wartości dodanej w świetle dyrektywy 2006/112/WE Rady w sprawie wspólnego systemu podatku od wartości dodanej}

Zarówno przepisy dyrektywy ${ }^{2}$, jak i orzecznictwo TSUE pozwalają na sformułowanie i zdefiniowanie podstawowych zasad obowiązujących w ramach unijnego systemu podatku od wartości dodanej (VAT). Znajdują one swoje odniesienie rzecz jasna również w przepisach polskiej ustawy o podatku od towarów i usług, jako jednego z krajowych elementów tego systemu ${ }^{3}$.

Źródłem tych zasad jest art. 1 ust. 2 dyrektywy 2006/112/WE. Sto-sownie do treści tego przepisu zasada wspólnego systemu VAT polega na zastosowaniu do towarów i usług ogólnego podatku konsumpcyjnego dokładnie proporcjonalnego do ceny towarów i usług, niezależnie od liczby transakcji, które mają miejsce w procesie produkcji i dystrybucji poprzedzającym obciążenia tym podatkiem. Podatek od wartości dodanej, obliczony od ceny towaru lub usługi według stawki, która ma zastosowanie do takiego towaru lub usługi, jest wymagalny od każdej transakcji, po odjęciu kwoty podatku poniesionego bezpośrednio w różnych składnikach kosztów. Wspólny system VAT stosuje się aż do etapu sprzedaży detalicznej włącznie.

Pierwszą zasadą jest powszechność opodatkowania podatkiem od wartości dodanej. Wynika ona zarówno z zakresu przedmiotowego, jak i podmiotowego opodatkowania i polega na konieczności objęcia opodatkowaniem całej konsumpcji, z uwzględnieniem jedynie enumeratywnie określonych w treści przepisów wyjątków. Analiza art. 2 ust. 1 dyrektywy 2006/112/WE pozwala na wskazanie kryteriów granicznych umożliwiających prawidłowe zastosowanie tej zasady. Przede wszystkim opodatkowaniem objęte są czynności odpłatne, zarówno w zakresie dostawy towarów, jak i świadczenia usług (z zachowaniem rzecz jasna ustawowych wyjątków przewidujących również opodatkowanie niektórych czynności nieodpłatnych ${ }^{4}$ ), a poza tym czynności te muszą być dokonywane przez podmiot działający w charakterze podatnika. Zasadą powszechności opodatkowania nie są zatem objęte usługi czy też dostawy mające swoje źródło w majątkach prywatnych (osobistych), które nie posiadają znamion działalności gospodarczej. Niezwykle istotnego znaczenia nabiera więc autonomiczna na gruncie przepisów o podatku VAT definicja działalności gospodarczej, określająca zakres przedmiotowy zastosowania zasady powszechności opodatkowania ${ }^{5}$.

${ }^{2}$ Dyrektywa 2006/112/WE Rady z dnia 28 listopada 2006 r. w sprawie wspólnego sytemu podatku od wartości dodanej, Dz.Urz. UE L 347, s. 1 ze zm.

${ }^{3}$ Ustawa z dnia 11 marca 2004 r. o podatku od towarów i usług, tekst jedn.: Dz.U. z 2017 r. poz. 1221 ze zm., dalej jako ustawa VAT.

${ }^{4}$ Przykładowo art. 7 ust. 2 i art. 8 ust. 2 ustawy VAT.

${ }^{5}$ Art. 15 ustawy VAT. 
Z powszechnością opodatkowania ściśle związana jest zasada wielofazowości i proporcjonalności podatku VAT. Jak bowiem jednoznacznie wynika z treści wspomnianego wyżej art. 1 ust. 2 dyrektywy 2006/112/WE, opodatkowaniem objęte są wszystkie fazy dostawy towarów oraz świadczenia usług aż do finalnego etapu tych czynności, tj. dostawy (świadczenia) na rzecz ostatecznego odbiorcy - konsumenta. Jednocześnie zaś w każdej kolejnej fazie obrotu opodatkowaniu podlega jedynie owa wartość dodana, czyli wartość ustalona po odliczeniu kwoty opodatkowanej już uprzednio, na wcześniejszych etapach dostawy (świadczenia). Kluczowe znaczenie w prawidłowej realizacji tej zasady ma kwestia właściwego ustalenia podstawy opodatkowania. Co prawda obecnie przepisy art. 29a ustawy VAT zostały w dużym stopniu doprecyzowane, niemniej w poprzednim stanie prawnym bardzo duże wątpliwości budziła chociażby kwestia tzw. kosztów dodatkowych i ustalania podstawy opodatkowania. Przykładem tego był fakt skierowania przez NSA do Trybunału pytania prejudycjalnego w tej sprawie, zakończonego wydaniem wyroku w sprawie C-224/11 (tzw. sprawa BGŻ Leasing) ${ }^{6}$.

Nie mniej istotna jest tutaj kwestia opodatkowania konsumpcji, czyli ostatniej fazy procesu dostawy towarów oraz świadczenia usług. Docelowo bowiem, jak już wcześniej wspomniano, faktyczny ciężar opodatkowania podatkiem od towarów i usług ponieść ma konsument, czyli ostateczny nabywca danego towaru lub usługi na swoje prywatne, osobiste potrzeby. Trybunał wielokrotnie w swoich orzeczeniach wskazywał na szczególne znaczenie tej kwestii w zakresie systemu podatku VAT. Wymownym przykładem jest chociażby wyrok z dnia 3 października $2006 \mathrm{r}$. w sprawie C-475/07 (Banca popolare di Cremona Soc. Coop. Arl v. Agenzia Entrate Ufficio Cremona), w którym podniesiono, że końcowe obciążenie podatkowe ponosi ostatecznie wyłącznie konsument ${ }^{7}$.

Swoistą klamrą, spinającą oraz dopełniającą wspólny system podatku od wartości dodanej, jest tytułowa zasada neutralności podatku dla podatnika. Zasada ta ma fundamentalne znaczenie $\mathrm{w}$ zakresie opodatkowania VAT i wyraża się poprzez możliwość dokonywania przez podatników odliczenia podatku naliczonego, związanego z czynnościami wykonywanymi $\mathrm{w}$ ramach prowadzonej przez nich działalności gospodarczej. Ma ona ścisły związek z omówionymi pokrótce wyżej zasadami powszechności oraz wielofazowości i proporcjonalności opodatkowania, jak również z zasadą faktycznego opodatkowania konsumpcji. Zasada neutralności podatku VAT którą szerzej omówię w kolejnym rozdziale - wyraża się zarówno poprzez jego potrącalność (czyli właśnie możliwość odliczenia), jak i możliwość

${ }^{6}$ Por. też M. Bącal, D. Dominik-Ogińska, M. Militz, T. Siennicki, Zasady prawa unijnego $w$ VAT, Warszawa 2013, s. 99 i n.

${ }^{7}$ Por. także wyroki TS z dnia 6 października 2005 r. w sprawie C-291/03, MyTravel plc v. Commissioners of Customs \& Excise, Legalis nr 71295 oraz z dnia 14 lutego $1985 \mathrm{r}$. w sprawie 268/83, D.A. Rompelman i E.A. Rompelman-Van Deelen v. Minister van Financiën, Legalis nr 102314. 
uzyskania przez podatnika zwrotu nadwyżki podatku naliczonego nad podatkiem należnym. Jak podkreśla doktryna, realizacja zasady neutralności VAT polega również na stworzeniu przez ustawodawstwa takich rozwiązań legislacyjnych, w ramach których podatek zapłacony przez podatnika (naliczony) w cenie towarów i usług nabytych w związku z prowadzoną działalnością gospodarczą (pojawia się tu po raz kolejny kwestia zdefiniowana pojęcia działalności gospodarczej) może zostać odliczony, nie stanowiąc dla tego podatnika faktycznego obciążenia kosztowego ${ }^{8}$.

\section{Zasada neutralności jako jedna z podstawowych zasad systemu podatku od wartości dodanej (VAT)}

Trybunał w swoim orzecznictwie wielokrotnie podkreślał, że zasada neutralności ma na celu całkowite zwolnienie przedsiębiorcy od kosztów podatku VAT zapłaconego w toku prowadzonej przez niego działalności gospodarczej. Przykładowo w uzasadnieniu wyroku w sprawie C-37/95 wskazał, że „wspólny system podatku VAT gwarantuje w ten sposób, iż wszelka działalność gospodarcza, niezależnie od jej celu lub rezultatu jest opodatkowana w sposób całkowicie neutralny pod warunkiem, że działalność ta podlega temu podatkowi"

Jak już wcześniej wspomniano, praktyczna realizacja zasady neutralności podatku VAT dla jego podatników przejawia się poprzez jego potrącalność (odliczanie podatku naliczonego) oraz możliwość uzyskania jego zwrotu w przypadku wystąpienia nadwyżki podatku naliczonego nad należnym.

Warunki, jakie musi spełnić podatnik w celu dokonania odliczenia podatku naliczonego (potrącenia) są określone w treści art. 178-182 dyrektywy 2006/112/WE, jak również w art. 86-88 ustawy VAT. Nie jest przedmiotem tego opracowania szczegółowe ich omawianie, niemniej należy wskazać, że podstawowym warunkiem dokonania odliczenie jest bezpośredni związek nabywanych przez podatnika towarów i usług z prowadzoną działalnością gospodarczą. Przykładowo w uzasadnieniu wyroku w sprawie C-4/94 Trybunał wskazał, że odliczenie przysługuje podatnikowi jedynie w sytuacji, gdy związek pomiędzy podatkiem naliczonym przy nabyciu a podatkiem należnym $\mathrm{z}$ tytułu działalności gospodarczej ma charakter bezpośredni i bezsporny - a zatem nie przysługuje m.in. podatnikowi, który wykorzystuje nabyte towary i usługi w związku z czynnością zwolnioną z podatku, nawet jeżeli docelowym efektem miałoby być wykonanie czynności opodatkowanej ${ }^{10}$.

${ }^{8}$ Tak m.in. J. Zubrzycki, Leksykon VAT, t. I, Wrocław 2017, s. 53.

${ }^{9}$ Wyrok TS z dnia 15 stycznia 1998 r. w sprawie C-37/95, Państwo Belgijskie v. Ghent Coal Terminal NV, Legalis nr 151244.

${ }^{10}$ Wyrok TS z dnia 6 kwietnia 1995 r. w sprawie C-4/94, BLP Group plc v. Commissioners of Customs \& Excise, Legalis nr 102597. 
Niezwykle istotną kwestią w zakresie dokonania przez podatnika potrącenia podatku jest moment jego dokonania. Jest rzeczą oczywistą, że neutralność nie może mieć w tym wymiarze znaczenia bezpośredniego, natychmiastowego. Wszak podatnik musi wpierw dokonać nabycia określonych towarów czy usług i ponieść (chwilowo) koszt podatku VAT, a dopiero po zakończeniu pewnego okresu rozliczeniowego ma możliwość odzyskania tego wydatku poprzez odpowiednie zmniejszenie kwoty podatku należnego za ten okres. Niemniej należy zgodzić się z twierdzeniem, że taki model umożliwia praktyczną realizację zasady neutralności podatku VAT ${ }^{11}$.

$\mathrm{W}$ świetle powyższych rozważań trzeba zauważyć, że bardzo ważne jest ustalenie odpowiedniej długości okresu, w którym to podatnik musi ponosić faktyczny koszt podatku - innymi słowy, wprowadzenie przez ustawodawcę przepisów umożliwiających dokonanie potrącenia w relatywnie niedługim czasie. Stosownie do treści art. 167 dyrektywy 2006/112/WE prawo do odliczenia powstaje w momencie, gdy podatek, który podlega odliczeniu, staje się wymagalny. Przepis ten uzależnia zatem powstanie prawa do dokonania potrącenia od uprzedniego powstania po stronie sprzedawcy obowiązku podatkowego - w efekcie zapewnia państwom członkowskim swoistą neutralność finansową, a przez to również stabilizację budżetową. W przeciwnym razie to budżet państwa byłby zobowiązany do „kredytowania" podatników korzystających z prawa do odliczenia.

Drugim elementem pozwalającym na praktyczną realizację zasady neutralności podatku VAT jest możliwość uzyskania przez podatników zwrotu nadwyżki podatku naliczonego nad podatkiem należnym. Podobnie jak w przypadku dokonywania potrącenia również i zwrot może nastąpić nie w sposób natychmiastowy, a po zakończeniu danego okresu rozliczeniowego. Jak stanowi art. 183 dyrektywy 2006/112/WE, w przypadku gdy za dany okres rozliczeniowy kwota odliczeń przekracza kwotę VAT należnego, państwa członkowskie mogą dokonać zwrotu lub przenieść nadwyżkę na następny okres rozliczeniowy w oparciu o ustalone przez siebie warunki. Na podstawie tego przepisu państwa członkowskie dysponują pewnym zakresem swobody $\mathrm{w}$ ustalaniu warunków dokonywania zwrotu nadwyżki podatku podatnikom. Wprowadzając wewnętrzne uregulowania, nie mogą jednak w żaden sposób naruszać ani podważać istoty zasady neutralności, na co wielokrotnie wskazywał w swoim orzecznictwie Trybunał. Przykładowo $\mathrm{w}$ wyroku $\mathrm{w}$ sprawie C-78/00 podniesiono, że warunki zwrotu nadwyżki VAT ustalone przez państwo członkowskie muszą umożliwiać podatnikowi odzyskanie całości kredytu wynikającego $\mathrm{z}$ tejże nadwyżki. Oznacza to również, że zwrot powinien być dokonywany $\mathrm{w}$ rozsądnym czasie, a przyjęta metoda zwrotu nie może wiązać się dla podatnika $\mathrm{z}$ ryzykiem finansowym ${ }^{12}$. W uzasadnieniu wyroku $\mathrm{w}$ sprawie

${ }^{11}$ Tak m.in. M. Bącal, D. Dominik-Ogińska, M. Militz, T. Siennicki, Zasady..., s. 67 i n.

${ }^{12}$ Wyrok TS z dnia 25 października 2001 r. w sprawie C-78/00, Komisja Wspólnot Europejskich v. Republika Włoska, Legalis nr 103027. 
C-400/98 Trybunał wskazał, że naruszeniem zasady neutralności jest odmawianie podatnikowi prawa do odliczenia podatku naliczonego aż do momentu uzyskania pierwszej sprzedaży ${ }^{13}$. Zdaniem Trybunału przejawami naruszenia zasady neutralności są wszelkie utrudnienia w uzyskiwaniu przez podatników zwrotów podatku VAT, takie jak wydłużanie przez państwa członkowskie terminów zwrotów lub wprowadzania dodatkowych warunków do ich uzyskania ${ }^{14}$.

Istotnym aspektem zasady neutralności jest wreszcie obowiązek równego traktowania. Trybunał bardzo szczegółowo omówił tę kwestię w uzasadnieniu wyroku w połączonych sprawach C-259/10 oraz C-260/10 ${ }^{15}$. Wskazał m.in., że odmienne traktowanie pod względem podatku VAT dwóch usług identycznych lub podobnych, zaspokajających te same potrzeby konsumenta, stanowi naruszenie zasady neutralności podatku. Nie ma przy tym potrzeby dodatkowego stwierdzenia faktycznego zakłócenia konkurencji pomiędzy nimi.

Zatem istotą owego równego traktowania jest obowiązek zapobiegania wszelkim działaniom (również legislacyjnym oraz procesowym) które mogłyby w efekcie prowadzić do różnego traktowania podobnych do siebie usług w świetle systemu opodatkowania podatkiem od towarów i usług. Nie ma przy tym znaczenia forma prawna podmiotów świadczących takie usługi $i^{16}$.

\section{Stosowanie przepisów dyrektywy 2006/112/WE w polskim systemie prawnym}

Z chwilą przystąpienia Polski do Unii Europejskiej przepisy unijne stały się jednym ze źródeł prawa obowiązujących w systemie krajowym. Co prawda unijne dyrektywy, w przeciwieństwie do rozporządzeń, nie mają mocy bezpośrednio obowiązującej w przepisach prawa krajowego, niemniej orzecznictwo Trybunału jednoznacznie wskazuje na możliwość takiego właśnie - bezpośredniego - stosowania przepisów dyrektywy przez podatników w określonych sytuacjach. Jest to możliwe przede wszystkim wtedy, gdy państwo członkowskie w określonym terminie nie wydało środków implementacyjnych wymaganych przez dyrektywę, a jej przepisy są bezwarun-

${ }^{13}$ Wyrok TS z dnia 8 czerwca 2000 r. w sprawie C-400/98, Finanzamt Goslar v. Brigitte Breitsohl, Legalis nr 102897.

${ }^{14}$ Wyrok TS z dnia 11 maja 2011 r. w sprawie C-107/10, C-107/10, Enel Maritsa Iztok 3 AD v. Direktor „Obzhalvane i upravlenie na izpalnenieto” NAP, Legalis nr 354798.

${ }^{15}$ Wyrok TS z dnia 10 listopada $2011 \mathrm{r}$. w połączonych sprawach C-259/10 oraz C-260/10, Commissioners for Her Majesty's Revenue and Customs v. The Rank Group plc, Legalis nr 381645.

${ }^{16}$ Wyrok TS z dnia 27 kwietnia 2006 r. w połączonych sprawach C-443/04 i C-444/04, H.A. Solleveld i J.E. van den Hout-van Eijnsbergen v. Staatssecretaris van Financiën, Legalis nr 74929. 
kowe i dostatecznie precyzyjne. W takim przypadku podatnik może powoływać się na jej postanowienia bezpośrednio ${ }^{17}$. Dodatkowo organy krajowe nie mogą powoływać się na konkretny przepis dyrektywy 2006/112/WE $\mathrm{w}$ sprawach przeciwko podatnikom w sytuacji, gdy obowiązkowa implementacja tego przepisu w systemie prawa krajowego nie została dokonana ${ }^{18}$.

Dla celów niniejszego opracowania jeszcze bardziej doniosłe znaczenie ma fakt - wielokrotnie podkreślanego w orzecznictwie Trybunału - obowiązku dokonywania prounijnej wykładni przepisów prawa krajowego m.in. przez sądy i organy administracji publicznej. Jest to wynik zasady pierwszeństwa prawa UE wobec prawa krajowego państw członkowskich. Zgodnie z tą zasadą wszystkie instytucje państw członkowskich - w tym przypadku sądy administracyjne oraz organy podatkowe i skarbowe - mają obowiązek podejmować wszelkie działania niezbędne do osiągnięcia celów Unii, w tym realizacji zasad ogólnych zharmonizowanego systemu podatku od wartości dodanej. Oznacza to m.in. konieczność dokonywania wykładni przepisów ustawy o podatku od towarów i usług zgodnie z treścią oraz celami dyrektywy 2006/112/WE ${ }^{19}$.

Trybunał wskazał w szczególności, że stosując prawo krajowe, sąd krajowy jest zobowiązany dokonywać wykładni tego prawa, tak dalece jak to możliwe, w świetle i celu dyrektywy, aby osiągnąć jej cel, a w ten sposób wypełnić art. 249 ust. 3 Traktatu o WE. Co ważne, Trybunał uznał, że samo przyjęcie środków krajowych prawidłowo implementujących dyrektywę nie wyczerpuje jej skutków, gdyż należy jeszcze zapewnić, aby ten środek krajowy, służący prawidłowej implementacji, był stosowany w sposób umożliwiający realizację zamierzonego przez dyrektywę celu ${ }^{20}$.

W tym miejscu należy jednakże podkreślić, że obowiązek stosowania wykładni prounijnej nie może mieć charakteru powszechnie obowiązującego. Praktyka orzecznicza Naczelnego Sądu Administracyjnego wskazuje bowiem, że prounijna wykładnia prawa powinna być stosowana wyłącznie wówczas, gdy wykładnia językowa nie prowadzi do odpowiedzi co do treści przepisów prawa krajowego. Wykładnia prounijna nie powinna być natomiast stosowana, gdy będzie prowadziła do rezultatów sprzecznych z efektami wykładni językowej, mogłoby to bowiem doprowadzić do niedopuszczalnej wykładni contra legem. NSA podniósł również, że „przepisy prawa krajowego należy wykładać, uwzględniając stosowne regulacje pra-

${ }^{17}$ Por. m.in. wyrok TS z dnia 19.01.1982 r. w sprawie 8/81, Ursula Becker v. Finanzamt Münster-Innenstadt, Legalis nr 54456 oraz wyrok TS z dnia 18 stycznia $2001 \mathrm{r}$. w sprawie C-150/99, Państwo Szwedzkie v. Stockholm Lindöpark AB i Stockholm Lindöpark AB v. Państwo Szwedzkie, Legalis nr 103000.

${ }^{18}$ Wyrok TS z dnia 8 października 1987 r. w sprawie 80/86, Postępowanie karne przeciwko Kolpinghuis Nijmegen BV, Legalis nr 103903.

${ }^{19}$ Podobnie J. Zubrzycki, Leksykon VAT..., s. 61.

${ }^{20}$ Wyrok ETS z dnia 11 lipca 2002 r. w sprawie C-62/00, Marks \& Spencer plc v. Commissioners of Customs \& Excise, Legalis nr 101041. 
wa UE. Zasada ta jednak nie ma charakteru bezwzględnie obowiązującego w szczególności wówczas, gdy prawo unijne ma charakter dyrektywy (ze swej istoty skierowanej do państw członkowskich, mających obowiązek doprowadzenia prawa krajowego do stanu realizującego normy zawarte w dyrektywach); nie może być stosowana taka wykładnia prawa krajowego, która będzie prowadziła do nakładania na podatnika obowiązków nieprzewidzianych wprost w prawie krajowym" ${ }^{\prime 2}$.

Również Trybunał w uzasadnieniu wyroku w sprawie C-91/92 podniósł, że sąd krajowy w procesie wykonywania obowiązku dokonywania wykładni prawa wewnętrznego w świetle brzmienia i celu dyrektywy nie może wykraczać poza wyraźne brzmienie przepisu prawa krajowego. Oznaczałoby to bowiem przyzwolenie na to, aby bez właściwej transpozycji przez państwo określonego przepisu dyrektywy do prawa krajowego sąd krajowy mógł w drodze wykładni nakładać na obywatela obowiązek wynikający $z$ tej dyrektywy wbrew unormowaniu krajowemu ${ }^{22}$.

Jak już wcześniej wspomniałem, do właściwego stosowania prawa unijnego - w tym przepisów dyrektywy 2006/112/WE - zobowiązane są nie tylko sądy, ale także organy administracji publicznej, w tym skarbowej. Podkreśla to zarówno orzecznictwo Trybunału, jak i sądów administracyjnych. W szczególności w uzasadnieniu wyroku w sprawie 103/88 Trybunał wskazał, że organy administracyjne są zobowiązane w taki sam sposób jak sąd krajowy do stosowania przepisów wspólnotowych (obecnie unijnych) oraz do powstrzymywania się od stosowania przepisów prawa krajowego, które są z nimi sprzeczne ${ }^{23}$. Analogiczne stanowisko przedstawiały wielokrotnie sądy administracyjne ${ }^{24}$.

\section{Analiza wybranych orzeczeń Trybunału i Naczelnego Sądu Administracyjnego w zakresie praktycznej realizacji zasady neutralności podatku}

\subsection{Status podatnika a prawo do odliczenia podatku}

Jednym z najistotniejszych aspektów zasady neutralności podatku VAT jest - jak już wcześniej wspomniano - możliwość potrącenia podatku przez podatników. W tym zakresie warto przeanalizować orzecznictwo Trybuna-

${ }^{21}$ Wyroki NSA: z dnia 23 marca 2009 r., I FPS 6/08, Legalis nr 138675; z dnia 13 maja 2008 r., I FSK 600/07, Legalis nr 105241 oraz z dnia 25 czerwca 2008 r., I FSK 743/07, Legalis $\mathrm{nr} 565434$.

${ }^{22}$ Wyrok TS z dnia 14 lipca 1994 r. w sprawie C-91/92, Paola Faccini Dori v. Recreb Srl, Legalis nr 54468.

${ }^{23}$ Wyrok TS z dnia 22 czerwca 1989 r. w sprawie 103/88, Fratelli Constanzo v. Commune di Milano, LEX nr 127572.

${ }^{24}$ Por. wyrok WSA w Bydgoszczy z dnia 9 stycznia 2007 r., I SA/Bd 711/06, Legalis nr 113823 oraz wyrok WSA w Gliwicach z dnia 30 października 2006 r., III SA/Gl 609/06, Legalis nr 295310. 
łu oraz NSA dotyczące możliwości odliczenia podatku poniesionego z tytułu wydatków inwestycyjnych przed rozpoczęciem wykonywania czynności w ramach działalności gospodarczej.

Dla przypomnienia, art. 167 dyrektywy 2006/112/WE ustanawia zasadę, zgodnie z którą prawo do odliczenia powstaje w momencie, gdy podatek, który podlega odliczeniu, staje się wymagalny. Przepis ten nie uzależnia zatem wprost możliwości odliczenia podatku od statusu prawnego podatnika, wskazując jako warunek konieczny wymagalność podatku należnego po stronie dostawcy.

Tymczasem art. 88 ust. 4 ustawy VAT stanowi, że obniżenia kwoty lub zwrotu różnicy podatku należnego nie stosuje się do podatników, którzy nie są zarejestrowani jako podatnicy VAT czynni, z wyłączeniem określonych przypadków. A zatem polski ustawodawca w treści tego przepisu ustanawia wprost wyjątek od zasady potrącalności podatku, uzależniając takie prawo od dokonania formalnej rejestracji.

W takim stanie prawnym pojawia się uzasadniona wątpliwość co do możliwości odliczenia VAT z tytułu wydatków poniesionych przez dany podmiot przed dokonaniem rejestracji - chociażby $z$ tytułu nabycia usług prawnych związanych z założeniem działalności gospodarczej.

W orzecznictwie Trybunału dotyczącym tej kwestii bardzo silnie akcentowana jest konieczność ścisłej wykładni zasady neutralności podatku, która ma zapewnić podatnikom możliwość uniknięcia kosztów związanych $\mathrm{z}$ podatkiem VAT z tytułu nabycia towarów i usług związanych $\mathrm{z}$ wykonywaniem czynności opodatkowanych. I tak w wyroku w sprawie C-400/98, Finanzamt Goslar v. Brigitte Breitsohl Trybunał wskazał, że osoba, która ma potwierdzony obiektywnymi dowodami zamiar rozpoczęcia prowadzenia działalności gospodarczej, a która ponosi uprzednie wydatki inwestycyjne w tym celu, musi być uznawana za podatnika, a co się z tym wiąże - musi posiadać prawo do niezwłocznego odliczenia podatku VAT zapłaconego z tytułu wydatków inwestycyjnych poniesionych w celu przyszłego wykonywania czynności opodatkowanych. Prawo takie jest niezależne od formalnego rozpoczęcia wykonywania działalności przedsiębiorstwa. W uzasadnieniu wyroku w sprawie 268/83, Rompelman Trybunał podkreślił wyraźnie, że jakakolwiek inna wykładnia przepisów dyrektywy 2006/112/WE sprzeciwiałaby się zasadzie neutralności podatku z uwagi na to, że obciążałaby podmiot kosztami VAT w toku jego działalności gospodarczej bez pozostawienia mu możliwości odliczenia tego podatku, a ponadto wprowadzałaby arbitralne rozróżnienie pomiędzy wydatkami inwestycyjnymi ponoszonymi przed formalnym rozpoczęciem prowadzenia działalności gospodarczej a wydatkami ponoszonymi w toku jego działalności. Trybunał wskazał zatem na konieczność bezwzględnego akceptowania zasady neutralności podatku, kładąc również nacisk na wspomniany przeze mnie wcześniej jeden z jej aspektów - obowiązek równego traktowania. 
Analizując powyższe orzeczenia, a także szereg innych podobnych wyroków Trybunału, można zauważyć szczególne znaczenie zasady neutralności podatku. Trybunał podkreśla wyraźnie, że wykładnia poszczególnych przepisów ustawy musi uwzględniać podstawowe znaczenie tej zasady dla całego systemu podatku od wartości dodanej. Co do możliwości odliczenia VAT z tytułu wydatków poniesionych przed formalnym rozpoczęciem prowadzenia działalności gospodarczej Trybunał jasno wskazuje, że prawo to jest niezależne od dokonania formalnej rejestracji. Kluczowe znaczenie dla powstania takiego prawa ma obiektywny, potwierdzony dowodami zamiar podjęcia działalności gospodarczej oraz wykonywania w jej ramach czynności opodatkowanych.

Dokonując wykładni przepisu art. 88 ust 4 ustawy VAT, Naczelny Sąd Administracyjny w uzasadnieniu wyroku w sprawie I FSK 378/06 ${ }^{25}$ również podniósł, że żaden z przepisów dyrektywy 2006/112/WE nie uzależnia prawa do obniżenia podatku należnego od wymogu formalnego, jakim jest rejestracja w charakterze podatnika podatku VAT. Sąd uznał, że zarówno przepis dyrektywy, jak również bogate orzecznictwo TS, wskazuje wyraźnie na to, że decydujący o prawie podatnika do skorzystania $\mathrm{z}$ obniżenia podatku należnego o wynikający $\mathrm{z}$ faktur podatek naliczony jest powstanie obowiązku podatkowego w odniesieniu do podatku podlegającego odliczeniu oraz związek zakupu z działalnością opodatkowaną przy spełnieniu warunków formalnych związanych z realizacją tego prawa. Wreszcie Sąd stwierdził, że prawo do obniżenia podatku należnego powstaje $\mathrm{w}$ okresie rozliczeniowym, w którym podatnik otrzymał fakturę lub dokument celny. Jego realizacja następuje poprzez złożenie deklaracji podatkowej wyrażającej wolę skorzystania przez podatnika z prawa do odliczenia i aby skutecznie zrealizować już powstałe uprawnienie, podatnik musi usunąć - najpóźniej przed skorzystaniem $\mathrm{z}$ prawa - wszelkie przesłanki negatywne, $\mathrm{w}$ tym brak rejestracji, która umożliwia identyfikowanie go jako podatnika.

Bardzo istotne znaczenie dla praktyki orzeczniczej w omawianym zakresie ma inny wyrok Naczelnego Sądu Administracyjnego. W sprawie I FSK 355/1226 Sąd zwrócił się bowiem z pytaniem prejudycjalnym do Trybunału. Pytanie dotyczyło właśnie możliwości odliczenia podatku VAT od wydatków poniesionych przez wspólników spółki przed jej rejestracją. Wydatki te miały charakter inwestycyjny i służyć miały przyszłej działalności opodatkowanej prowadzonej przez spółkę.

Odpowiedzi na zadanie pytanie Trybunał udzielił w wyroku z dnia 1 marca 2012 r. w sprawie C-280/10. Trybunał zwrócił przede wszystkim uwagę, że zgodnie z utrwalonym orzecznictwem na działalność gospodarczą może składać się wiele następujących po sobie czynności, a czynności przygotowawcze, takie jak przykładowo nabycie środków trwałych, powinny być

${ }^{25}$ Wyrok NSA z dnia 21 grudnia 2006 r., I FSK 378/06, LEX nr 288744.

${ }^{26}$ Wyrok NSA z dnia 20 lipca 2012 r., I FSK 355/12, LEX nr 1215685. 
zaliczane do działalności gospodarczej. Trybunał orzekła również, że zasada neutralności podatku VAT w odniesieniu do obciążenia podatkowego przedsiębiorstwa wymaga, aby pierwsze wydatki inwestycyjne dokonane na potrzeby i cele przedsiębiorstwa były uznawane za działalność gospodarczą oraz że z ową zasadą byłoby sprzeczne, gdyby rzeczona działalność rozpoczynała się dopiero w chwili, gdy nabyty środek trwały jest faktycznie wykorzystywany, to znaczy gdy powstaje dochód podlegający opodatkowaniu. Jakakolwiek inna interpretacja prowadziłaby do obciążenia podmiotu gospodarczego podatkiem VAT w ramach jego działalności gospodarczej, nie stwarzając możliwości odliczenia tego podatku, i wprowadzałaby arbitralne rozróżnienie między wydatkami inwestycyjnymi dokonanymi przed faktycznym wykorzystywaniem nieruchomości i w jego trakcie. W konsekwencji TS, powołując się na wspomniany już przeze mnie wcześniej wyrok w sprawie 268/83, uznał, że ktokolwiek dokonuje działań inwestycyjnych ściśle związanych z przyszłym wykonywaniem czynności opodatkowanych i koniecznych do tego celu, powinien być uważany za podatnika w rozumieniu dyrektywy 2006/112/WE.

Analizując przywołane wcześniej orzecznictwo NSA, należy stwierdzić, że wykładnia przepisu art. 88 ust. 4 ustawy VAT winna być dokonywana $\mathrm{z}$ pełnym respektowaniem zasady neutralności opodatkowania. Przede wszystkim należy bowiem rozróżnić sam moment powstania prawa do odliczenia od momentu skorzystania $\mathrm{z}$ tego prawa przez podatnika. Stosownie bowiem do treści art. 167 dyrektywy 2006/112/WE oraz art. 86 ust. 10 ustawy VAT prawo do dokonania potrącenia powstaje w momencie powstania obowiązku podatkowego u sprzedawcy towarów lub usług będących przedmiotem nabycia. Nie ma przy tym znaczenia dla samego powstania tego prawa, czy w danym momencie nabywca tych usług jest zarejestrowanym podatnikiem VAT ani też czy formalnie prowadzi już działalność gospodarczą. Istotny jest - zgodnie $\mathrm{z}$ innymi zasadami ogólnymi (proporcjonalności i wielofazowości) - związek nabytych towarów lub usług z przyszłymi czynnościami opodatkowanymi, jak również udowodniony zamiar ich świadczenia. Odrębną kwestią jest natomiast moment skorzystania przez podatnika $\mathrm{z}$ tego prawa. Jego realizacja następuje poprzez złożenie deklaracji podatkowej wyrażającej właśnie wolę skorzystania z nabytego uprzednio prawa. Aby skutecznie z niego skorzystać, podatnik musi wpierw usunąć wszelkie przesłanki negatywne, do których zalicza się m.in. brak formalnej rejestracji. Powyższa wykładnia weszła na stałe również do stanowiska aparatu skarbowego w tej sprawie. Przykładowo w interpretacji indywidualnej z dnia 31 marca 2017 r. Dyrektor Krajowej Informacji Skarbowej wskazał, że podatnik ma prawo do odliczenia podatku naliczonego od zakupów dokonanych przed rejestracją, pod warunkiem że w okresie, kiedy składana jest deklaracja VAT, widnieje już jako czynny podatnik VAT. Jak podkreślił organ skarbowy, z przepisów nie wynika, by posiadanie statusu podatnika 
VAT w momencie otrzymania faktury było warunkiem koniecznym do nabycia prawa do obniżenia kwoty podatku należnego. W momencie otrzymania faktury podatnik nabywa więc prawdo do odliczenia podatku VAT, lecz aby zrealizować to uprawnienie, musi posiadać status podatnika VAT czynnego ${ }^{27}$.

Zbliżona do zagadnienia omówionego wyżej jest kwestia istnienia prawa do odliczenia podatku naliczonego przez podatników, którzy w wyniku błędu nie dokonali rejestracji jako podatnicy VAT czynni, świadcząc usługi mylnie zakwalifikowane jako zwolnione z VAT, tudzież podatników, którzy nie mieli świadomości objęcia zakresem ustawy VAT z uwagi na domniemany brak znamion działalności gospodarczej w wykonywanych czynnościach. W licznych orzeczeniach Trybunał wskazał jednoznacznie, że przepisy dyrektywy 2006/112/WE sprzeciwiają się przepisom krajowym, na mocy których prawa do odliczenia naliczonego podatku od wartości dodanej należnego lub zapłaconego od towarów lub usług wykorzystanych do celów transakcji podlegających opodatkowaniu odmówiono podatnikowi mającemu jednak zapłacić podatek, który powinien był on pobrać, wyłącznie z tego względu, że nie był on zarejestrowany do celów podatku od wartości dodanej przy dokonywanych tych transakcji ${ }^{28}$. Trybunał podkreślił przy tym, że identyfikacja podatnika dla celów podatku VAT oraz obowiązek zgłoszenia przez podatnika rozpoczęcia, zmiany i zakończenia działalności (art. 213-214 dyrektywy 2006/112/WE oraz art. 96 ustawy VAT) stanowią jedynie wymogi formalne do celów kontrolnych, które nie mogą podważać w szczególności prawa do odliczenia podatku VAT, jeżeli materialne przesłanki powstania tego prawa zostały spełnione. A zatem podatnikowi podatku od wartości dodanej nie można utrudniać wykonywania prawa do odliczenia z tego tylko względu, że nie został on zidentyfikowany dla celów podatku VAT przed wykorzystaniem towarów zakupionych w ramach swojej działalności podlegającej opodatkowaniu.

Podobne stanowisko zajął również Naczelny Sąd Administracyjny w uzasadnieniu wyroku z dnia 9 lipca 2010 r. w sprawie I FSK 1132/0929. Sąd podniósł m.in., że sprzeczne z zasadą neutralności i proporcjonalności jest pozbawienie podatnika na podstawie art. 88 ust. 4 ustawy o VAT uwzględnienia $\mathrm{w}$ rozliczeniu podatkowym podatku naliczonego $\mathrm{w}$ sytuacji, gdy podatnik, błędnie przeświadczony, że korzysta ze zwolnienia z podatku

${ }^{27}$ Interpretacja indywidualna nr 1462-IPPP3.4512.86.2017.1.IG.

${ }^{28}$ Por. m.in. wyrok TS z dnia 9 lipca 2015 r. w sprawie C-183/14, Radu Florin Salomie i Nicolae Vasile Oltean v. Directia Generală a Finantelor Publice Cluj, Legalis nr 1325661; wyrok TS z dnia 6 lutego 2014 r. w sprawie C-424/12, SC Fatorie SRL v. Direcția Generală a Finanţelor Publice Bihor, Legalis nr 758431; wyrok TS z dnia 21 października 2010 r. w sprawie C-385/09, C-385/09, Nidera Handelscompagnie BV v. Valstybine mokesčiu inspekcija prie Lietuvos Respublikos finansu ministerijos, Legalis nr 265971 oraz wyrok TS z dnia 26 czerwca 2012 r. w sprawie C-335/09P, Rzeczpospolita Polska v. Komisja Europejska, Legalis nr 183306.

${ }^{29}$ Wyrok NSA z dnia 9 lipca 2010 r., I FSK 1132/09, LEX nr 593515. 
od towarów i usług na podstawie art. 113 ust. 1 ustawy o VAT, mimo ciążącego na nim obowiązku nie dokonał zgłoszenia rejestracyjnego, o którym mowa w art. 96 ustawy o VAT. W sytuacji gdy rozliczenia należnego zobowiązania w podatku od towarów i usług dokonuje organ podatkowy w drodze decyzji, jest on zobowiązany uwzględnić podatek naliczony wynikający z okazanych przez podatnika faktur uprawniających do pomniejszenia podatku należnego. Dodatkowo Sąd raz jeszcze podkreślił, że realizacja zasady neutralności VAT wyraża się w stworzeniu takich rozwiązań legislacyjnych, w ramach których podatek naliczony (zapłacony) przez podatnika w cenie nabytych towarów i usług dla celów jego działalności opodatkowanej tym podatkiem może zostać odliczony, nie stanowiąc tym samym dla podatnika obciążenia kosztowego. Konieczność przestrzegania tej zasady przez systemy legislacyjne Państw Członkowskich szczególnie stanowczo akcentowana jest przez Trybunał Sprawiedliwości Unii Europejskiej, który w swoim orzecznictwie wielokrotnie podkreślał, że prawo do odliczenia zostało wprowadzone, aby całkowicie uwolnić przedsiębiorcę od kosztów VAT zapłaconego lub podlegającego zapłacie w toku jego działalności gospodarczej.

Analogiczne do powyższego stanowisko zajmował Naczelny Sąd Administracyjny również w innych swoich orzeczeniach ${ }^{30}$.

Widać więc wyraźnie, że zarówno Trybunał, jak i NSA, mając na uwadze przede wszystkim zasady neutralności podatku, jak również proporcjonalności, uznają prawo do odliczenia podatku naliczonego za jedno z podstawowych praw podatnika, powstające i istniejące niezależnie od spełnienia określonych wymogów formalnych.

Kluczowe i niepodważalne znaczenie zasady neutralności podatku zostało podniesione przez Trybunał w uzasadnieniu wyroku w sprawie C-277/14, będącego niejako odpowiedzią na skierowane przez Naczelny Sąd Administracyjny pytania prejudycjalne dotyczące zgodności określonych przepisów ustawy VAT z przepisami dyrektywy 2006/112/WE ${ }^{31}$. W tej sprawie NSA powziął wątpliwość, czy nabywca usługi ma prawo do odliczenia podatku w sytuacji, w której faktura została wystawiona przez podmiot, który nie był rzeczywistym dostawcą towaru i nie ma możliwości ustalenia tożsamości rzeczywistego dostawcy towaru oraz zobowiązania go do zapłaty podatku.

W odpowiedzi na postawione pytania Trybunał podkreślił po raz kolejny, że prawo do odliczenia stanowi zasadę podstawową wspólnego systemu podatku VAT i co do zasady nie podlega ograniczeniu, a przysługuje ono bezpośrednio w stosunku do całego podatku obciążającego transak-

${ }^{30}$ Por. m.in. wyrok NSA z dnia 11 marca 2010 r., I FSK 267/09, Legalis nr 293605; z dnia 16 grudnia 2009 r., I FSK 1172/08, Legalis nr 744500; z dnia 27 kwietnia 2010 r., I FSK 1849/09, Legalis nr 274382.

${ }^{31}$ Wyrok TS z dnia 22 października 2015 r. w sprawie C-277/14, PPUH Stehcemp sp.j. Florian Stefanek, Janina Stefanek, Jarosław Stefanek v. Dyrektor Izby Skarbowej $w$ Łodzi, Legalis nr 1384805 oraz postanowienie NSA z dnia 6 marca 2014 r., I FSK 516/13, Legalis nr 1366390. 
cje powodujące naliczenie podatku. System odliczeń ma bowiem na celu całkowite uwolnienie przedsiębiorcy od ciężaru podatku VAT zapłaconego $\mathrm{w}$ ramach prowadzonej działalności gospodarczej. Trybunał podniósł również, że co do wymogów formalnych warunkujących skorzystanie z prawa do odliczenia przepisy dyrektywy 2006/112/WE wskazują na konieczność posiadania przez dany podmiot statusu podatnika oraz posiadanie prawidłowo wystawionej faktury (zawierającej określone elementy) na zakup towaru lub usługi związanych z wykonywaną czynnością opodatkowaną. Jeżeli chodzi zaś o dostawcę towarów, to winien on posiadać status podatnika VAT. Nie są natomiast - zdaniem Trybunału - przesłankami warunkującymi prawo do odliczenia kryteria takie jak istnienie dostawcy towarów lub jego prawo do wystawiania faktur, tudzież posiadanie niezbędnych (zgodnie z prawem krajowym) koncesji bądź odpowiedniego miejsca prowadzenia działalności gospodarczej. Trybunał uznał również, że wspomniany wcześniej status podatnika w stosunku do dostawcy nie może zależeć od przestrzegania obowiązków podatnika takich jak m.in. składanie deklaracji podatkowych i zapłata należnego podatku.

W powyższym zakresie Trybunał jednoznacznie podkreślił zatem kluczowe dla całego systemu podatku VAT znaczenie zasady neutralności podatku dla jego podatników. W świetle przywołanego orzeczenia organy podatkowe nie mogą odmówić prawa do odliczenia tylko na tej podstawie, iż dostawca towarów dokonał wskazanych uchybień. Zdaniem Trybunału przepisy dyrektywy 2006/112/WE należy interpretować w ten sposób, że sprzeciwiają się one przepisom krajowym odmawiającym podatnikowi prawa do odliczenia podatku zapłaconego od dostarczanych mu towarów $\mathrm{z}$ uwagi na to, że faktura została wystawiona przez podmiot, który w świetle kryteriów przewidzianych przez te przepisy należy uznać za podmiot nieistniejący i nie ma możliwości ustalenia tożsamości rzeczywistego dostawcy.

W tym miejscu należy jednak przypomnieć, że Trybunał stwierdził również, iż jeżeli sąd krajowy wykaże, że świetle obiektywnych przesłanek i bez wymagania od podatnika, aby dokonał ustaleń, do których nie jest zobowiązany, ów podatnik wiedział lub powinien był wiedzieć, iż dostawa wiązała się z przestępstwem w zakresie podatku VAT, wtedy stosowne prawo do odliczenia mu nie przysługuje. Trybunał podniósł, że zakres czynności sprawdzających, jakie powinien podjąć podatnik w stosunku do dostawcy, zależy każdorazowo od okoliczności konkretnej sprawy, niemniej w żadnym wypadku nie oznacza to, iż organy podatkowe mogą w sposób generalny wymagać, aby podatnik badał, czy wystawca faktury dysponował danymi towarami i był w stanie je dostarczyć, tudzież czy wywiązuje się on z obowiązku złożenia deklaracji i zapłaty podatku VAT.

W tym miejscu należy sięgnąć do orzecznictwa Trybunału i Naczelnego Sądu Administracyjnego w zakresie dotyczącym czynności, jakie powinien dokonać podatnik dla zapewnienia sobie możliwości skorzystania z prawa do odliczenia podatku z konkretnej faktury. 
W wyrokach w sprawach C-33/13 oraz połączonych sprawach C-80/11 i C-142/11 Trybunał wprowadził pojęcie "przezornego przedsiębiorcy"32. Zdaniem Trybunału, jeżeli istnieją przesłanki, by podejrzewać nieprawidłowości lub naruszenie prawa, przezorny przedsiębiorca powinien, zależnie od okoliczności konkretnego przypadku, zasięgnąć informacji na temat podmiotu, u którego zamierza nabyć towary lub usługi, w celu upewnienia się co do jego wiarygodności. Dodatkowo Trybunał wskazał, tytułem zasady ogólnej, że można w uzasadniony sposób wymagać od podatnika, który zamierza skorzystać z prawa do odliczenia podatku VAT, aby upewnił się, że charakter dostarczonych towarów odpowiada charakterowi towarów, na które wystawiono fakturę.

Analizując powyższe stwierdzenia, należy podkreślić, że określenie „upewnić się" oznacza per analogiam, iż jeżeli tylko podatnik będzie miał jakiekolwiek wątpliwości co do rzetelności sprzedawcy, powinien odstąpić od transakcji, względnie podjąć zdecydowane działania w celu potwierdzenia zarówno statusu dostawcy, samej dostawy, jak i stopnia i zakresu wypełniania przez dostawcę obowiązków w zakresie podatku VAT, w szczególności takich jak składanie deklaracji i zapłata podatku.

W świetle powyższych rozważań i wskazówek Trybunału warto w tym miejscu przedstawić wybrane orzeczenia Naczelnego Sądu Administracyjnego dotyczące tej kwestii.

W uzasadnieniu wyroku w sprawie I FSK 708/13 NSA wskazał, że niezbędne jest zindywidualizowanie rozpatrywania każdej sprawy w zakresie pozbawienia podatnika prawa do odliczenia podatku naliczonego w aspekcie jego wiedzy lub możliwości wiedzy, że w ramach zakwestionowanej przez organy transakcji dostawca dopuścił się przestępstwa, lub że inna transakcja w łańcuchu dostaw, dokonana przed transakcją przeprowadzoną przez owego podatnika lub po niej, miała miejsce z naruszeniem ustawy $\mathrm{VAT}^{33}$. Wymaga to zbadania przestrzegania przez podatnika zasad należytej staranności kupieckiej, gdyż jeżeli występują przesłanki, by podejrzewać istnienie nieprawidłowości lub przestępstwa, przezorny przedsiębiorca powinien, zależnie od okoliczności konkretnego wypadku, zasięgnąć informacji na temat podmiotu, u którego zamierza nabyć towary lub usługi, w celu upewnienia się co do jego wiarygodności. Sąd stwierdził ponadto, że istotne jest, aby same okoliczności towarzyszące transakcji wskazywały, że nabywający towar lub usługę podatnik wykazał w niej staranność wymaganą w obrocie danym towarem (usługą), czyniąc tę transakcję przejrzystą (transparentną). W odniesieniu zaś do konkretnej sprawy będącej

${ }^{32}$ Zob. wyrok TS z dnia 6 lutego 2014 r. w sprawie C-33/13, Marcin Jagiełto v. Dyrektor Izby Skarbowej $w$ Łodzi, Legalis nr 966208 oraz wyrok z dnia 21 czerwca 2012 r. w sprawach połączonych C-80/11 i C-142/11, Mahagében kft v. Nemzeti Adó- és Vámhivatal Dél-dunántúli Regionális Adó Föigazgatósága i Péter Dávid v. Nemzeti Adó- és Vámhivatal Észak-alföldi Regionális Adó Főigazgatósága, Legalis nr 486894.

${ }^{33}$ Wyrok NSA z dnia 27 maja 2014 r., I FSK 708/13, Legalis nr 951306. 
przedmiotem orzeczenia (kwestia dostawy paliw) Sąd wskazał ponadto, że w zakresie owej przezorności kupieckiej mieści się z całą pewnością weryfikowanie uprawnień (koncesji) dostawcy na handel paliwem.

W uzasadnieniu wyroku w sprawie do I FSK 940/14 Naczelny Sąd Administracyjny podniósł, że w przypadku obiektywnego stwierdzenia, że pomiędzy faktycznymi a zafakturowanymi dostawami towarów istnieją rozbieżności, faktury te w zakresie, w jakim stwierdzają czynności, które nie zostały dokonane, nie dają nabywcy podstawy do odliczenia podatku naliczonego i nie ma co do zasady przesłanek, aby w zakwestionowanym zakresie co do ich rzetelności korzystały z tzw. domniemania dobrej wiary, gdyż staranny nabywca nie powinien przyjmować faktur, które dokumentują czynności nieodzwierciedlające rzeczywistości ${ }^{34}$. Sąd wskazał jednakże, iż wszystko to nie wyklucza możliwości wykazania przez podatnika, iż mimo dochowania należytej staranności w następstwie wskazanych przez niego okoliczności mogło dojść do przyjęcia przez niego faktur stwierdzających czynności, które w jakiej części nie zostały dokonane.

Wreszcie w uzasadnieniu wyroku w sprawie I FSK 260/12 NSA, odnosząc się wprost do jednego z przywołanych przeze mnie wyżej orzeczeń Trybunału, podniósł, że „w kwestii wykazania podatnikowi braku z jego strony należytej staranności kupieckiej, której zachowanie pozwoliłoby mu na ustrzeżenie się przed oszukańczą działalnością firmującego i podmiotu firmowanego, niewystarczające jest powoływanie się na powszechną wiedzę, że w branży obrotu złomem tego typu sytuacje często mają miejsce, gdyż w kontekście kryteriów dochowania przez podatnika należytej staranności sformułowanych przez TS głównie w wyroku z dnia 21 czerwca 2012 r. wydanego w sprawach połączonych C-80/11 i C-142/11, należy jednoznacznie wskazać jakich to konkretnych czynności zaniedbał podatnik, których dokonanie i uwzględnienie pozwalałoby mu na stwierdzenie, że zakwestionowane faktury pochodzą od podmiotu jedynie firmującego obrót, a faktycznym dostawcą otrzymywanych towarów jest inny podmiot (firmowany)"35.

\subsection{Nadużycie prawa do odliczenia}

W tym miejscu należy zwrócić uwagę na koncepcję nadużycia prawa $\mathrm{w}$ tym przypadku prawa do potrącenia podatku, która na gruncie prawa podatkowego sformułowana została po raz pierwszy w wyroku Trybunału w sprawie C-255/02 ${ }^{36}$.

Przede wszystkim Trybunał wskazał dwa elementy konieczne do stwierdzenia nadużycia prawa: zestaw obiektywnych okoliczności, w których po-

${ }^{34}$ Wyrok NSA z dnia 13 października 2015 r., I FSK 940/14, Legalis nr 1348520.

${ }^{35}$ Wyrok NSA z dnia 12 marca 2013 r., I FSK 260/12, Legalis nr 760628.

${ }^{36}$ Wyrok TS z dnia 21 lutego 2006 r. w sprawie C-255/02, Halifax plc, Leeds Permanent Development Services Ltd i County Wide Property Investments Ltd v. Commissioners of Customs \& Excise, Legalis nr 74647. 
mimo formalnego przestrzegania warunków przewidzianych przez przepisy prawa unijnego, cel tych przepisów nie został osiągnięty, i element subiektywny, na który składa się wola uzyskania korzyści na podstawie przepisów unijnych poprzez sztuczne stworzenie warunków dla skorzystania z nich.Dodatkowo Trybunał podniósł, że mając na uwadze zasadę neutralności podatku, prawo do odliczenia nadwyżki podatku naliczonego nad podatkiem należnym jest integralną część mechanizmu podatku VAT i co do zasady nie może być ograniczane, obejmując bezpośrednio cały podatek naliczony na poprzednich etapach obrotu. Niemniej przepisy dyrektywy 2006/112/WE powinny być interpretowane $\mathrm{w}$ ten sposób, iż sprzeciwiają się one prawu podatnika do odliczenia naliczonego podatku VAT, jeżeli transakcje, z których wynika to prawo, stanowią nadużycie. Dla stwierdzenia istnienia owego nadużycia wymagane jest, po pierwsze, aby dane transakcje, pomimo iż spełniają formalne przesłanki przewidziane $\mathrm{w}$ odpowiednich przepisach dyrektywy i ustawodawstwa krajowego skutkowały uzyskaniem korzyści podatkowej, której przyznanie byłoby sprzeczne z celem tych przepisów. Po drugie, z ogółu obiektywnych okoliczności powinno również wynikać, iż zasadniczym celem tych transakcji jest uzyskanie korzyści podatkowej.

A zatem Trybunał uznał, że zasada neutralności podatku i prawo do jego potrącenia nie znajdują zastosowania w sytuacji, gdy pomimo faktu, że dana czynność została dokonana przez podatników w ramach prowadzonych przez nich działalności gospodarczych, jej wykonanie miało prowadzić do uzyskania korzyści podatkowej. W takim bowiem przypadku przepisy dyrektywy 2006/112/WE, a przede wszystkim jej cel są sprzeczne ze skutkiem takiej transakcji.

Powyższa konstrukcja została ujęta w licznych orzeczeniach Naczelnego Sądu Administracyjnego ${ }^{37}$. Przykładowo w uzasadnieniu wyroku w sprawie I FSK 2/15 Sąd wskazał, że o przeprowadzeniu danej transakcji w warunkach nadużycia prawa można mówić w sytuacji, gdy ciąg zdarzeń gospodarczych został przez jej strony świadomie ułożony w taki sposób, by umożliwić kupującemu uzyskanie zwrotu podatku naliczonego przy jednoczesnym nieodprowadzeniu podatku należnego przez sprzedawcę. Sąd podniósł przy tym, że z obiektywnych okoliczności danej sprawy musi wynikać, że celem, a więc świadomym założeniem leżącym u podstaw zorganizowania łańcucha transakcji, musi być sztuczne wygenerowanie po stronie skarżącej korzyści podatkowej sprzecznej z ratio legis prawa do odliczenia. Nie ma przy tym, zdaniem Sądu, znaczenia fakt, iż nie był to jedyny cel stron, z orzecznictwa Trybunału Sprawiedliwości wynika bowiem, że osiągnięcie takiej korzyści nie musi być wyłącznym

${ }^{37}$ Por. wyroki NSA z dnia 5 września 2016 r., I FSK 2/15, Legalis nr 1512270; z dnia 25 kwietnia 2017 r., I FSK 1226/15, Legalis nr 1611973 oraz z dnia 25 lutego 2015 r., I FSK 93/14, Legalis nr 1217985. 
celem transakcji, by uznać, że doszło do nadużycia prawa - wystarczy, by był to cel zasadniczy.

W uzasadnieniu wyroku I FSK 1226/15 NSA stwierdził, że jeżeli transakcje, pomimo iż spełniają formalne przesłanki przewidziane w przepisach prawa, skutkowałyby uzyskaniem korzyści podatkowej, której przyznanie byłoby sprzeczne $\mathrm{z}$ celem tych przepisów, to są to czynności następujące w ramach nadużycia prawa. Ich zasadniczym celem nie jest bowiem osiągnięcie zysku będącego wynikiem prowadzenia rzeczywistej działalności gospodarczej, lecz uzyskanie korzyści podatkowej.

\section{Zakończenie}

Analiza powyższych orzeczeń wskazuje jednoznacznie, że zasada neutralności podatku, przejawiająca się zwłaszcza możliwością dokonania przez podatników potrącenia podatku naliczonego, stanowi kluczowy element całego systemu podatku od wartości dodanej. Sądy podnoszą, że jakiekolwiek ograniczenia tego prawa muszą mieć charakter wyjątkowy i być interpretowane w sposób ścisły. W tym zakresie szczególnego znaczenia nabiera koncepcja nadużycia prawa do odliczenia, która ma zapobiegać wykorzystywaniu systemu potrącania podatku do tworzenia tzw. karuzel podatkowych. Niemniej i tutaj to organy skarbowe, jeżeli chcą pozbawić podatnika prawa do odliczenia, muszą w sposób wyraźny wykazać, że nie dochował on należytej staranności w relacjach handlowych.

Bibliografia

Bącal M., Dominik-Ogińska D., Militz M., Siennicki T., Zasady prawa unijnego w VAT, Warszawa 2013.

Zubrzycki J., Leksykon VAT, t. I, Wrocław 2017.

\section{Akty prawne}

Dyrektywa 2006/112/WE Rady z dnia 28 listopada 2006 r. w sprawie wspólnego systemu podatku od wartości dodanej, Dz.Urz. UE L 347, s. 1 ze zm.

Ustawa z dnia 11 marca 2004 r. o podatku od towarów i usług, tekst jedn.: Dz.U. z 2017 r. poz. 1221 ze zm.

\section{Orzecznictwo}

Wyrok TS z dnia 19.01.1982 r. w sprawie 8/81, Ursula Becker v. Finanzamt Münster-Innenstadt, Legalis nr 54456.

Wyrok TS z dnia 14 lutego 1985 r. w sprawie 268/83, D.A. Rompelman i E.A. Rompelman-Van Deelen v. Minister van Financiën, Legalis nr 102314.

Wyrok TS z dnia 8 października 1987 r. w sprawie 80/86, Postępowanie karne przeciwko Kolpinghuis Nijmegen BV, Legalis nr 103903.

Wyrok TS z dnia 22 czerwca 1989 r. w sprawie 103/88, Fratelli Constanzo v. Commune di Milano, LEX nr 127572.

Wyrok TS z dnia 14 lipca 1994 r. w sprawie C-91/92, Paola Faccini Dori v. Recreb Srl, Legalis nr 54468. 
Wyrok TS z dnia 6 kwietnia 1995 r. w sprawie C-4/94, BLP Group plc v. Commissioners of Customs \& Excise, Legalis nr 102597.

Wyrok TS z dnia 15 stycznia 1998 r. w sprawie C-37/95, Państwo Belgijskie v. Ghent Coal Terminal NV, Legalis nr 151244.

Wyrok TS z dnia 8 czerwca 2000 r. w sprawie C-400/98, Finanzamt Goslar v. Brigitte Breitsohl, Legalis nr 102897.

Wyrok TS z dnia 18 stycznia 2001 r. w sprawie C-150/99, Państwo Szwedzkie v . Stockholm Lindöpark AB i Stockholm Lindöpark AB v. Państwo Szwedzkie, Legalis $\mathrm{nr} 103000$

Wyrok TS z dnia 25 października 2001 r. w sprawie C-78/00, Komisja Wspólnot Europejskich v. Republika Włoska, Legalis nr 103027.

Wyrok TS z dnia 11 lipca 2002 r. w sprawie C-62/00, Marks \& Spencer plc v. Commissioners of Customs \& Excise, Legalis nr 101041.

Wyrok TS z dnia 6 października 2005 r. w sprawie C-291/03, MyTravel plc v. Commissioners of Customs \& Excise, Legalis nr 71295.

Wyrok TS z dnia 21 lutego 2006 r. w sprawie C-255/02, Halifax plc, Leeds Permanent Development Services Ltd i County Wide Property Investments Ltd v. Commissioners of Customs \& Excise, Legalis nr 74647.

Wyrok TS z dnia 21 października 2010 r. w sprawie C-385/09, C-385/09, Nidera Handelscompagnie BV v. Valstybine mokesčiu inspekcija prie Lietuvos Respublikos finansu ministerijos, Legalis nr 265971.

Wyrok TS z dnia 11 maja 2011 r. w sprawie C-107/10, C-107/10, Enel Maritsa Iztok 3 AD v. Direktor „Obzhalvane i upravlenie na izpalnenieto” NAP, Legalis nr 354798.

Wyrok TS z dnia 10 listopada 2011 r. w połączonych sprawach C-259/10 oraz C-260/10, Commissioners for Her Majesty's Revenue and Customs v. The Rank Group plc, Legalis nr 381645.

Wyrok z dnia 21 czerwca 2012 r. w sprawach połączonych C-80/11 i C-142/11, Mahagében kft v. Nemzeti Adó- és Vámhivatal Dél-dunántúli Regionális Adó Főigazgatósága i Péter Dávid v. Nemzeti Adó- és Vámhivatal Észak-alföldi Regionális Adó Főigazgatósága, Legalis nr 486894.

Wyrok TS z dnia 26 czerwca 2012 r. w sprawie C-335/09P, Rzeczpospolita Polska v. Komisja Europejska, Legalis nr 183306.

Wyrok TS z dnia 6 lutego 2014 r. w sprawie C-424/12, SC Fatorie SRL v. Direcţia Generală a Finanţelor Publice Bihor, Legalis nr 758431.

Wyrok TS z dnia 6 lutego 2014 r. w sprawie C-33/13, Marcin Jagiełto v. Dyrektor Izby Skarbowej w Łodzi, Legalis nr 966208.

Wyrok TS z dnia 9 lipca 2015 r. w sprawie C-183/14, Radu Florin Salomie i Nicolae Vasile Oltean v. Directia Generală a Finantelor Publice Cluj, Legalis nr 1325661.

Wyrok TS z dnia 22 października 2015 r. w sprawie C-277/14, PPUH Stehcemp sp.j. Florian Stefanek, Janina Stefanek, Jarosław Stefanek v. Dyrektor Izby Skarbowej $w$ Łodzi, Legalis nr 1384805.

Wyrok NSA z dnia 21 grudnia 2006 r., I FSK 378/06, LEX nr 288744.

Wyrok NSA z dnia 13 maja 2008 r., FSK 600/07, Legalis nr 105241.

Wyrok NSA z dnia 25 czerwca 2008 r., I FSK 743/07, Legalis nr 565434.

Wyrok NSA z dnia 23 marca 2009 r., I FPS 6/08, Legalis nr 138675.

Wyrok NSA z dnia 16 grudnia 2009 r., I FSK 1172/08, Legalis nr 744500. 
Wyrok NSA z dnia 11 marca 2010 r., I FSK 267/09, Legalis nr 293605. Wyrok NSA z dnia 27 kwietnia 2010 r., I FSK 1849/09, Legalis nr 274382. Wyrok NSA z dnia 9 lipca 2010 r., I FSK 1132/09, LEX nr 593515.

Wyrok NSA z dnia 20 lipca 2012 r., I FSK 355/12, LEX nr 1215685. Wyrok NSA z dnia 12 marca 2013 r., I FSK 260/12, Legalis nr 760628. Postanowienie NSA z dnia 6 marca 2014 r., I FSK 516/13, Legalis nr 1366390. Wyrok NSA z dnia 27 maja 2014 r., I FSK 708/13, Legalis nr 951306. Wyrok NSA z dnia 25 lutego 2015 r., I FSK 93/14, Legalis nr 1217985. Wyrok NSA z dnia 13 października 2015 r., I FSK 940/14, Legalis nr 1348520. Wyrok NSA z dnia 5 września 2016 r., I FSK 2/15, Legalis nr 1512270. Wyrok NSA z dnia 25 kwietnia 2017 r., I FSK 1226/15, Legalis nr 1611973. Wyrok WSA w Bydgoszczy z dnia 9 stycznia 2007 r., I SA/Bd 711/06, Legalis nr 113823.

Wyrok WSA w Gliwicach z dnia 30 października 2006 r., III SA/Gl 609/06, Legalis nr 295310.

Interpretacja indywidualna nr 1462-IPPP3.4512.86.2017.1.IG.

Streszczenie

W artykule omówiono rolę orzecznictwa Naczelnego Sądu Administracyjnego i Trybunału Sprawiedliwości UE w realizacji prawa podatnika do potrącenia podatku naliczonego jako przejawu zasady neutralności podatku VAT dla podatników. W pierwszej części przedstawiono podstawowe zasady podatku od towarów i usług: powszechności opodatkowania, wielofazowości oraz proporcjonalności, a także podstawową na gruncie podatku od towarów i usług zasadę neutralności. Szczegółowo omówiono zasadę neutralności, a szczególnie jej podstawowe aspekty: prawo podatnika do potrącenia podatku naliczonego, prawo do uzyskania zwrotu nadwyżki podatku naliczonego nad należnym oraz obowiązek równego traktowania podatników. Następnie przeanalizowano możliwość stosowania przepisów dyrektywy 2006/112/WE (tzw. dyrektywy VAT) w polskim systemie prawnym, zaprezentowano także wybrane przykłady orzecznictwa NSA i TS w zakresie prawa do potrącenia podatku. Omawiane wyroki dotyczą odliczeń z tytułu wydatków poniesionych przed rozpoczęciem prowadzenia działalności, jak również możliwości odliczenia podatku z czynności dokonanych przed zarejestrowaniem podatnika w rejestrze VAT. W ostatniej części artykułu poruszono problem nadużycia przez podatnika prawa do odliczenia na podstawie analizy wybranych orzeczeń NSA i TS.

Słowa kluczowe: podatek od towarów i usług, zasada neutralności, odliczenie podatku, Trybunał Sprawiedliwości, Naczelny Sąd Administracyjny

The Taxpayer's Rights as Regards the Deduction of Input Tax in the Jurisprudence of the Supreme Administrative Court Taking into Consideration EU Legislation and Judgments of the Court of Justice of the European Union

Abstract

The article deals with the role of the Supreme Administrative Court and the Court of Justice of the EU in the implementation of the taxpayer's right to deduct input tax as a manifestation of the neutrality principle of VAT for the taxpayers. The first part sets 
out the basic principles of the tax on goods and services: the principles of universality of taxation, the principle of multiphase and proportionality, and finally the principle of neutrality on the basis of the tax on goods and services. The following section contains a detailed discussion of the principle of neutrality and in particular its fundamental aspects: the right of the taxpayer to deduct input tax, the right to recover excess input tax and the obligation of equal treatment of the taxpayers. The third chapter deals with issues concerning the applicability of the provisions of Directive 2006/112/EC (the 'VAT Directive') in the Polish legal system. Finally, the fourth chapter contains an analysis of selected examples of the case law of the Supreme Administrative Court and the Court of Justice of the EU on the right to deduct the tax. These judgments concern the taxpayer's ability to deduct tax for expenses incurred before the commencement of business as well as the possibility of deducting tax from activities performed before the taxpayer's registration in the VAT register. The last part of the article deals with the problem of abuse by the taxpayer of the right to deduct on the basis of analysis of selected judgements by the Supreme Administrative Court and the Court of Justice of the EU.

Keywords: VAT tax, neutrality principle, deduct input tax, Court of Justice of the EU, Supreme Administrative Court 